\title{
Teacher-Student Relationship and Its Urgencies in Indonesia: a Literature Review
}

\author{
Eko Hardi Ansyah \\ Fakultas Psikologi \\ Universitas Muhammadiyah Sidoarjo \\ Sidoarjo, Indonesia \\ ekohardi1@umsida.ac.id
}

\author{
Cholichul Hadi \\ Fakultas Psikologi \\ Universitas Airlangga \\ Surabaya, Indonesia
}

\author{
Seger Handoyo \\ Fakultas Psikologi \\ Universitas Airlangga \\ Surabaya, Indonesia
}

\begin{abstract}
The problems of teacher-student relation so far in Indonesia are still not considered. This article is a literature review which aim to describe teacher-student relationships in more depth. It relates to history, concept, measurements, internal or external influencing factors, and their impact on behavior or other psychological aspects. By analyzing 36 articles from from various sources, this literature review also addresses the urgencies of research on teacher-student relationship in Indonesia. The implications of this study are contribute to the implementation of teacher-student relationship research in Indonesia, the development of educational psychology, and on enhancing the student self-development programs in schools.
\end{abstract}

Keywords-teacher-student relationships; character education; students self-development programs.

\section{INTRODUCTION}

The issue of the teacher-student relationship has been discussed related to constructing and paradigms of educators in several decades. As delivered by Lyons [1] that the heart of teaching and learning in the classroom is a relationship between teachers with students. In addition, the existence of a positive relationship between teachers with students will bring motivation ), quality, and success in school [2] for students itself. This relationship also becomes an important variable that forms the wellbeing of teachers and students at the school [3]. Therefore, this shows that the teacher-student relationship is a very important variable which is not only for students but also teachers themselves.

Currently, There are many empirical studies about teacherstudent relationship [4]. In fact that there is little literature review about teacher-student relationship. As literature review conducted by Al Nasseri et al. [5] shows that possitive teacher-student relationship influence students' learning.
However, the literature review is focused on how teacherstudent relationship impact to students' learning, yet which leads on how to deepen the teacher-student relationship in the context of Indonesia. Therefore, there is very little research on teacher-student relations in Indonesia. Whereas teacherstudent relationships are widely used in USA and the Netherlands as a study of human development [6]-[8].

Consequently, this paper aims to study teacher-student relationship and its urgencies Indonesia through exploring the literature. By knowing its urgencies, the researchers, especially Indonesian, will be interested in doing research about teacher-student relationship in Indonesian context.

\section{METHOD}

The literatures were obtained by searching different databases which include ScienceDirect, Proquest, Chengage, and Psych Info. In view of the apparent paucity of literature on teacher-students relationship, the review period covers the period from 1990 to 2016. To find the current educational issues in Indonesia, we also searched from the online media listed on 2017 until 3 years before. The criteria being included for selecting articles ware a research-based articles and using teacher-student relationship as the keyword. Furthermore the other articles which did not match the criteria ware excluded. Based on these criteria, we found 36 articles, books, and news which are reviewed.

\section{RESULTS AND DISCUSSION}

\section{A. Historical Perspective}

The study of the relationship between teacher and student begins with Dewey's writing [9] which states the importance of the relationship between the child and what he observes, feels and loves in the school context. Because the connection help the child to increase curiosity, open minds and make the child happy and increase the spirit to learn. Vygotsky reinforced this concept by conveying that the support given to 
students in the context of performance and learning of challenging tasks is the main view of his concept about the zone of proximal development / ZTD [10]. The core of this ZTD is the importance of adult role in optimizing the children potention in completing the task.

The similar study done by Rosenthal [11] through his research on the influence of expectations on student performance concluded that there is a strong indication that instruction is not as simple as demonstration, modeling and reinforcement, however complex mediation processes socially and psychologically. In addition, Eccles \& Roeser's study [12] conveyed that the school context including teacher attitudes and behaviors towards students has proven to have strong relationships with motivation, self-perception, and achievement of student goals. The Bioecological Model of human development developed by Bronfenbrenner and Morris [13] also emphasized the importance of the student's social process. The bioecological model defines development as a phenomenon of sustainability and change in the characteristics of human biopsychology, either as an individual or a group. The phenomenon extends over life, between successive generations, and through historical time, be it the past and the future by four properties, such as process, person, context, and time. From these pespective, we could conclude that teacherstudent relationship plays an important role for developing the students.

\section{B. Theoretical Perspective}

Teacher-student relationship concept developed from attachment theory [10] which is based on the attachment theory, people's motivation to be a certain part can be known in one's attach behavior. The psychological purpose of the affectional bond between the individual with an attach figure, e.g. the nurse-child and adult romantic relationship, are to attain or maintain emotional security. The experience gained is that the inherent relationship becomes internalized into mental representation (e.g. internal working models or mental schemas) of relationships that guide the processing of social information within a material that is consistent and predictable. This is an important consequence for future social relations. According to attachment theory, the internal work model of relations consists of information generated about self, others, and other self-relationships, which shape the development of new relationships. Research on the hierarchical structure of this model suggests that relations of relational experiences are internalized at different levels of generalization. Repetition on interpersonal experiences across the context of relationships resulting a global interpersonal orientation. People also construct domain-specific models for various relationships (e.g., romantic, familial, and work relations) as well as specific relationships for relationships with others such as parents, spouses, or a friend [14].

Consequently, teacher who adjacent to his/her student physically, also believed to form a relational-specific model with each child in their class. This model contains the teacher's image of the child, her own sense of interaction with the child and also the internalized feelings that color these images. This particular relationship model is considered to be nested in a domain-specific model of the teaching profession, nested in a global model containing general beliefs about relationships and views. The representation of personal relationships with students is related to and is reciprocally influenced by the professional and personal views of the teacher. Thus, relationships with individual students can have a significant effect on the self-esteem and teacher welfare. Even Davis suggests that teachers apply the concept of dual relationships when teachers use their relationships with students to meet their own psychological needs [14]. The use of this attachment theory is also confirmed by Pianta himself [2], [10]. Based on this attachment theory, Pianta [15] developed a well-validated Teacher-Student Scale to measure teachers' perceptions of conflict, closeness, and dependence on their relationships with students.

\section{Core Concept of Teacher-Student Relationship}

According to Pianta, Hamre, \& Stuhlman teacher-student relationship is a dyadic system between teacher and student which adheres to the principles of a dynamic behavioral system, involves a multicomponent unity through crosscutting interaction and within the multiple levels of organization and influence [10]. They suggested that teacherstudent relationship is as an abstraction from the representation of organizational levels or a form within the system matrix and greater interaction.

As described in the book manual for professional-scale teacher-student relationship, Pianta [15] explained the notion of teacher-student relation is the teacher's perception of a relationship with a particular student viewed from patterns of conflict, closeness, and dependence. Teacher-student relationship defined as conflict, closeness, and dependence aspects score obtained from teacher-student relations scale. A high total score indicates a high quality of relationship that is typically characterized by low teacher-student conflicts, high teacher-student closeness, and a lack of student dependence on teachers. The operational definition for each of the aspect as follows: 1) conflict; this aspect measures the degree to which a teacher perceives his or her relationship with a particular student with negative and conflictual. High conflict scores indicate that the teacher is arguing with the student, perceiving the student is angry or unpredictable, and consequently the teacher feels emotionally drained and believes that he or she is ineffective. 2) Closeness; This aspect measures the degree to which teachers experience affection, warmth, and open communication with particular students. High closeness scores indicate that the relationship has a warm character, and the teacher believes that he is effective because the student is using his teacher as a source of support. High closeness scores also reflect a greater sense of knowing on behalf of the teacher that the student is good and that the student can effectively use the teacher as a resource. 3) Dependence; this aspect measures the degree to which a teacher perceives a particular student is highly dependent on it. A high dependency score indicates that the student reacts strongly to the separation from the teacher, asks for help when it is not needed, and consequently the teacher becomes concerned over the student's dependence. [15]. 


\section{Teacher-Student Relationship Measurement}

Teacher-Student Relationship Scale (TSRS) are constructed by Pianta [16] using three aspects, namely conflict, closeness, and dependence as a measurement of teacher-student relationship [15]. Nevertheless, there are several advantages and disadvantages of this scale. There are five advantages of this scale. First, The TSRS has been used since 1991 [2] and has been widely used in the United States [6], [14] for the benefit of educational development [7]. The results of this study using TSRS had implications for the evolve of developmental psychology [17]. Second, TSRS had been published to be accessed by public in University of Virginia website and the users of this measurement had been permitted to use it freely. The author only requests the translated TSRS in any language beside english to his email, i.e.pianta@virginia.edu [18]. The third advantage of this scale is that TSRS has good reliability with alpha score $=0,86$ [19]. The fourth advantage is about the reability of both aspects of TSRS. Conflict aspect has alpha reliability $=0,86$ and closeness aspect has alpha reliability $=0,85$. It means that both of these aspects has a high confidence to measure teacherstudent relationship as well. The last advantage of this measurement is that this scale has good items validity using item-total correlation. It range from 0,13 to 0,71 with $\mathrm{N}=1.535$ [15].

Dispite of the advantages, TSRS has three disadvantages, namely first that this scale never been tried out or conducted in Indonesia. Therefore the norm of the scale existed could not be used to Indonesian participants. Second, dependence aspect has the lowest coefficent alpha campared to another aspects of teacher-student relationship, i.e. conflict coefficient $r=-0,347$; conflict coefficient $\mathrm{r}=0,725$; and closeness coefficient $\mathrm{r}=-$ 0,$913 ; \rho=0,001$. Consequently, the recent research about teacher-student relationship do not use dependence aspect to measure teacher-student relationship. The third disadvantage of TSRS is which stated by Spilt, et al. [14] that the use of dependence by some researchers is not used as an indicator of teacher-student relationships because some items of scale used are more likely to be closer to children's adjustment problems in school, e.g. "This kid is very dependent on me" and "This kid asks for my help when he really does not need that help".

\section{E. Factors which are Determine High-Low of Teacher- Student Relationship}

There are some internal factors of a person could determine high-low of teacher-student relationship. They are genetic factor, namely dopaminergic gene [20] and gender and race [6]. Other factors are related to the psychological factors of a person such as self-determination [21] and teacher's gratitude to the children [22]. The child's temperament is also considered to be an internal factor affecting the strength of the teacher-student relationship, although it does not rule out the teacher's own temperament [23] as well as the effortful control of the student [24]. Ofcourse, there are great deal possibilities for further teacher-student relationship researchers to explore what kind of internal factors which could determine this teacher-student relationship, using a neurological approach, or by using a concept such as choice theory, where the practice of choice theory in counseling was found able to improve the child's relationship [25].

The external factor of a person found to strengten the teacher-student relationship. The mother-children relationship determine teacher-student relationship [26]. Beside that, teacher-student relationship also could be predicted from the student relationship to their peers [27]. Children who are treated in child care for longer periods also tend to have problematic relationships with their teachers [6]. Similarly with the internal factors, according to Bioecological Model of Brofenbrenner, there are a great deal chances to study teacherstudent relationship from broaden environment context, such as school, community, even political policy of the government.

\section{F. Impacts of Teacher-Student Relationship}

Many studies about teacher-student relationship showed it influence to various important variables not only to the student, but also the teacher. Wentzel [28] found that the high teacher-student relationship could strengten interest and social responsibility of student. Likewise Pianta \& Hamre [2] stated that high academic achievement and low student misbehavior also predicted by possitive teacher-student relationship. Beside that are student adjustment at school [29], [30], student involvement at school, rule-breaking behavior [20], student outonomous motivation [21], and the successful competence based education implementation [31]. Not only for the student, the strength teacher-student relationship could improve the teacher well-being [3].

\section{G. The Current Educational Issues in Indonesian Context}

Indonesian government through National Education Ministry at current time develop a character education programme, namely "Program Penguatan Karakter" or Character Strengtening Programme which is known in Indonesian abbreviation as PPK [32]. At now, Character Strengtening Programme or PPK developed by the government on basic education level especially at elementary and secondary school level. This programme is being applied in three context, such as class, school, and community context [32]. However, this programme is still focusing on student daily habituation, extracurriculum activity, and integration of local content to curriculum [33] rather than to improve the teacher-student relationship.

In recent years, many cases which shown the low quality of teacher-student relationships have been emerging. Online newspapers displaying the issues of low quality teacherstudent relationships increased. We can easily see the problems of teacher-student relations through conflict [6], [10], [15]. Which in the worst level could be reflected in violence. Liputan6.com displayed teacher violence on students as many as 11 stories in the last three years [34]. The news headline include, such as "Noisy in the classroom, teacher closed the students mouth with tape during study", "Flash Indonesia: Students and parent hit the teacher until bloody", "Hit 4 pupils with shoes,' teacher in Sragen is polished". These news indicates the increasingly precarious question of teacherstudent relation in Indonesia. This opinion is also supported by data in Indonesia the question of this relation is increasingly 
seen with the fact of violence in children $84 \%$ happened in school. Indeed the trend is higher than the average rate in ASIA which is only $70 \%$ [35].

\section{H. The Urgencies of Teacher-Student Relationship in Indonesia}

According to the number of studies that explore teacherstudent relationships outside Indonesia, this becomes the next researcher challenge. Especially researchers in Indonesia to conduct research of cultural-based teacher-student relationship, given that currently only a few researchers in Indonesia who explore teacher-student relationships. Whereas the community problems related to the low quality of teacherstudent relation in Indonesia are quite large with the number of cases of violence by teachers on students or vice versa [36]. Based on literature sources related to research articles are currently still not found teacher-student relationship study using the subject in the context of Indonesia. This suggests that research on teacher-student relationship is an important research theme to be conducted in Indonesia.

\section{CONCLUSION}

From this literature review, we have known that teacherstudent relationship is a rare study in Indonesia. Eventhough it is very important which is known from the previous study related to the impacts of teacher-student relationship on many important variables of students and teachers and the number of current issues in indonesia which lead to the low quality of teacher-student relationship in Indonesia. Therefore, the study about this theme in Indonesia would be so challenging to enhance the psychological science and the improve of character education in Indonesia.

\section{ACKNOWLEDGMENT}

Special thank you for Universitas Airlangga and Universitas Muhammadiyah Sidoarjo which given me high quality access to literature source so give me chance to finish this literature review.

\section{REFERENCES}

[1] N. Lyons, "Dilemmas of Knowing: Ethical and Epistemological Dimensions of Teachers â $€^{\mathrm{TM}}$ Work and Development," Harv. Educ. Rev., vol. 60, no. 2, pp. 159-181, 1990 .

[2] B. K. Hamre and R. C. Pianta, "Early teacher-child relationships and the trajectory of children's school outcomes through eighth grade.," Child Dev., vol. 72, no. 2, pp. 625-638, 2001.

[3] L. Claessens et al., "Beginning and experienced secondary school teachers' self- and student schema in positive and problematic teacherstudent relationships," Teach. Teach. Educ., vol. 55, pp. 88-99, 2016.

[4] J. C. Barch, "On measuring student-teacher relationships: Sorting out predictors, outcomes, and schematic structure of students' internal relationship representations," 2015.

[5] Y. S. Al Nasseri, L. Renganathan, F. Al Nasseri, and A. Al Balushi, "Impact of Students-Teacher Relationship on Student's Learning: A Review of Literature," Int. J. Nurs. Educ., vol. 6, no. 1, p. 167, 2014.

[6] E. M. Jerome, B. K. Hamre, R. C. Pianta, and O. I. Way, "Teacherchild relationships from kindergarten to sixth grade: Early childhood predictors of teacher-perceived conflict and closeness," Sos. Dev., vol.
18, no. 4, pp. 915-945, 2014.

[7] NICHD, "Early child care and children's development in the primary grades: Follow-up results from the NICHD study of early child care on JSTOR," American Educational Research Journal. pp. 537-570, 2005.

[8] H. M. Y. Koomen, K. Verschueren, E. van Schooten, S. Jak, and R. C. Pianta, "Validating the student-teacher relationship scale: Testing factor structure and measurement invariance across child gender and age in a Dutch sample," J. Sch. Psychol., vol. 50, no. 2, pp. 215-234, 2012.

[9] J. Dewey, The child and the curriculum. Toronto: The University of Chicago Press, 1902.

[10] R. C. Pianta, B. Hamre, and M. Stuhlman, "Relationship between teachers and children," in Handbook of Psychology: Educational Psychology, vol. 7, W. M. Reynolds and G. E. Miller, Eds. New Jersey: John Wiley \& Sons, Inc., 2003, pp. 199-234.

[11] R. Rosenthal, "Interpersonal expectancy effects: A thity years perspective,” Curr. Dir. Psychol. Sci., vol. 3, pp. 176-179, 1994.

[12] J. S. Eccles and R. W. Roeser, "School and community influence on human development," in Developmental Psychology: An advanced textbook, no. January, M. H. Bornstein and M. E. Lamb, Eds. Mahwah, New Jersey: Lawrance Erlbaum Associates, 1999, pp. 503-554.

[13] U. Bronfenbrenner and P. A. Morris, "The bioecological model of human development," in Handbook of Child Psychology: Theoritical Models of Human Development, I., R. M. Lerner and W. Damon, Eds. New Jersey: John Wiley \& Sons, Inc., 2006, pp. 793-828.

[14] J. L. Spilt, H. M. Y. Koomen, and J. T. Thijs, "Teacher wellbeing: The Importance of teacher - student relationships," Educ. Psychol. Rev., vol. 23, pp. 457-477, 2011.

[15] R. C. Pianta, "Student-teacher relationship scale (STRS): Professional manual.” PAR, Psychological Assessment Resources, Inc., pp. 1-58, 2001

[16] R. C. Pianta, The student teacher relationship Scale. Charlottesvilee: University of Virginia, 1992.

[17] E. C. C. R. N. NICHD, "Does amount of time spent in child care predict socioemotional adjustment during the transition to kindergarten?," Child Dev., vol. 74, no. 4, pp. 976-1005, 2003.

[18] R. C. Pianta, "Measures developed by Robert C. Pianta, Ph.D.," University of Virginia. 2012.

[19] NICHD, “Teacher's relationship with child first grade student-teacher relationship scale," 2000.

[20] S. De Laet et al., "Teacher-student relationships and adolescent behavioral engagement and rule-breaking behavior: The moderating role of dopaminergic genes," J. Sch. Psychol., vol. 56, pp. 13-25, 2016.

[21] T. Jungert, B. Piroddi, and R. Thornberg, "Early adolescents??? motivations to defend victims in school bullying and their perceptions of student???teacher relationships: A self-determination theory approach,” J. Adolesc., vol. 53, pp. 75-90, 2016.

[22] K. Howells, "An exploration of the role of gratitude in enhancing teacher-student relationships," Teach. Teach. Educ., vol. 42, pp. 58-67, 2014.

[23] M. Oren and I. Jones, "The Relationships between child temperament, teacher-child relationships, and teacher-child interactions," Int. Educ. Stud., vol. 2, no. 4, pp. 122-133, 2009.

[24] A. Diaz et al., "Relations of positive and negative expressivity and effortful control to kindergarteners' student-teacher relationship, academic engagement, and externalizing problems at school," J. Res. Pers., 2015.

[25] E. H. Ansyah and E. W. Maryam, "Efektivitas intervensi milieu dan komunitas untuk meningkatkan motivasi berprestasi anak panti asuhan aisyiyah celep-sidoarjo," J. Ilm. Psikol. Terap., vol. 4, no. 1, pp. 113 $122,2016$. 
[26] R. C. Pianta, S. L. Nimetz, and E. Bennett, "Mother-child relationships, teacher-child relationships, and school outcomes in preschool and kindergarten," Early Child. Res. Q., vol. 12, no. 3, pp. 263-280, Jan. 1997.

[27] C. Wang, M. Hatzigianni, A. Shahaeian, E. Murray, and L. J. Harrison, "The combined effects of teacher-child and peer relationships on children's social-emotional adjustment," J. Sch. Psychol., vol. 59, pp. $1-11,2016$.

[28] K. R. Wentzel, "Social relationships and motivation in middle school: The role of parents, teachers, and peers.," J. Educ. Psychol., vol. 90, no. 2, pp. 202-209, 1998.

[29] S. H. Birch and G. W. Ladd, "The teacher-child relationship and children's early school adjustment," J. Sch. Psychol., vol. 35, no. 1, pp. 61-79, 1997 .

[30] R. C. Pianta, M. S. Steinberg, and K. B. Rollins, "The first two years of school: Teacher-child relationships and deflections in children's classroom adjustment," Dev. Psychopathol., vol. 7, no. 2, pp. 295-312, 1995.

[31] Z. Misbah, J. Gulikers, R. Maulana, and M. Mulder, "Teacher interpersonal behaviour and student motivation in competence-based vocational education: Evidence from Indonesia," Teach. Teach. Educ., vol. 50, pp. 79-89, 2015 .

[32] R. Belarminus, "Apa itu pendidikan karakter dalam program 8 jam belajar di sekolah," nasional.kompas.com, Jakarta, 14-Jun-2017.

[33] Kemdikbud RI, Konsep dan pedoman Penguatan Pendidikan Karakter: Tingkat sekolah dasar dan sekolah menengah pertama. Jakarta: Kementrian Pendidikan Nasional, 2017.

[34] Liputan6.com, "Kumpulan kekerasan guru terbaru hari Ini," liputan6.com, $2017 . \quad$ [Online]. $\quad$ Available: http://www.liputan6.com/tag/kekerasan-guru. [Accessed: 30-Jul-2017].

[35] N. Qodar, "Survei ICRW: 84\% Anak Indonesia Alami Kekerasan di Sekolah - News Liputan6.com," Liputan6, 2015. [Online]. Available: http://news.liputan6.com/read/2191106/survei-icrw-84-anak-indonesiaalami-kekerasan-di-sekolah.

[36] JPNN, "Angka kekerasan di dunia pendidikan meningkat - Page 2 JPNN," $\quad J P N N, \quad 2014 . \quad$ [Online]. Available: http://www.jpnn.com/news/angka-kekerasan-di-dunia-pendidikanmeningkat?page $=2$. [Accessed: 15-Jun-2017]. 